\title{
Prophet Sulaymān in Classical Persian Poetry: Semantics and Structure of the Image
}

\author{
A. V.Moiseeva \\ Institute of Oriental Manuscripts of the Russian Academy of Sciences, \\ 18, Dvortsovaya nab., St. Petersburg, 191186, Russian Federation
}

For citation: Moiseeva A. V. Prophet Sulaymān in Classical Persian Poetry: Semantics and Structure of the Image. Vestnik of Saint Petersburg University. Asian and African Studies, 2020, vol. 12, issue 3, pp. 398-414. https://doi.org/10.21638/spbu13.2020.306

The article discusses structure, semantic content, and functioning of the image of the Qur'anic prophet Sulaymān (Biblical Solomon) in Persian medieval poetry. Analysis of the poetic material leads to a conclusion about the main spheres of application of this image and its semantic connotations both in eulogistic and religious-mystical poetry. The article defines the main motifs of the Qur'anic story of this prophet that became a part of Persian poetic tradition and how they relate to the various themes that poets touch upon. For instance, motives of Sulaymān's power over winds and demons, as well as images of his throne and the ring that gave him that power, were used primarily in eulogies when poets compared their patrons to the legendary king. A special place in Sufi poetry is occupied by the image of the hoopoe and the motif of the bird's language that reveal topics of a disciple-mentor relationship and leadership in the path of mystical knowledge. As a global characteristic of Sulaymān's image, we can outline its ambivalence which has its roots in the biblical narrative, where along with wisdom one can find mention of Solomon's arrogance. Further exegetical tradition speaks of dethronement of Sulaymān by a demon as a punishment for arrogance. Later on, these themes can be found in Persian literature in the form of motifs of humility and frailty of the earthly life, which gained special meaning in the context of didactic and mystical poetry.

Keywords: Persian poetry, image, prophet Sulaymān, stories of prophets in the Qur'an, narrative, motive.

\section{Introduction}

Few literary images have spread in the world culture as widely as the image of biblical king Solomon did. Presented in the Old Testament as a historical person, over time his figure has become associated with numerous legends and was incorporated into colourful mosaic of the world literary tradition. Solomon becomes a character of the Quran, Islamic, Jewish and Christian lore, appears in European literature - both religious and didactic - and later in fiction. Over the years, the biblical king's wisdom, wealth and majesty became a source of inspiration for artists, writers and composers.

The fictionalization of Solomon's image took place at an early stage of commenting on biblical stories, when the king of Judea, described in the Old Testament, acquires

() Санкт-Петербургский государственный университет, 2020 
supernatural powers and finds magical helpers. Later on, these motifs were developed turning Solomon into a legendary literary image. He can talk to beasts and birds, control demons and winds; he is the owner of countless treasures and infinite wisdom.

In the Qur'an Sulaymān is called a prophet - nabi - that is, one of those who were chosen to bring the Revelation and the Word of God to men. The Qur'an speaks of 31 nabì, including the first prophet - Adam - and the last one - Muhammad - "the seal of prophets"; 25 of them have biblical prototypes. The three biblical characters most frequently mentioned in the Qur'an are Noah (Nūḥ), Abraham (Ibrāhīm) and Moses (Mūsā). They are described as being particularly important for the preparation of Muhammad's prophetic mission. At the same time, Sulaymān is mentioned relatively rarely: his name appears 17 times in different verses, but each of the episodes associated with him through a vast exegetical tradition gave rise to a corresponding set of motifs incorporated into literary reality of classical Persian poetry.

The present article deals with the story and poetic motifs associated with the image of Sulaymān in classical ${ }^{1}$ Persian literature. The objectives of this study are consistent with the direction outlined by A. E. Bertels in his work "Artistic Image in the Art of Iran": by analyzing the structure and semantics of the images that existed in the mind of a medieval Persian poet expand the frontiers of our knowledge about art of that period [2, p. 7-8]. Numerous scholarly works are aimed at solving this rather global problem. Analysis of the sources of Persian poetic imagery system is one of the directions of such studies. An important place among them is occupied by works that deal with analysis of the functioning of certain Qur'anic images in Persian poetry. Among the examples of such works are articles by various researchers discussing the images of Joseph (Yusuf) [e.g. 3-6] and Jesus (Isā) [7]. As for the character that became the subject of the present paper, we are aware of two works dealing directly with this image: "Influence of the Quranic story of Sulaymān on Persian literature" by Parīsā Dāvarì [8] and "Contamination of stories of Sulaymān and Jamshīd and its reflection in Persian literature" by Dizfūliān K. and Șuhrāyī Q. [9].

Davari's article contains a general description of Sulaymān's image and is based on a wide range of poetic sources - some of the examples in the present work are borrowed from there.

The other work is devoted to the issue of contamination of the images of Sulaymān and legendary Persian king Jamshīd - this phenomenon will be discussed below.

\section{Semantics of the image}

The key feature of prophet Sulaymān is the ambivalent nature of this character and the resulting ambiguity in the perception of his image in poetry. On the one hand, Sulaymān is an example of a wise king and a fair judge, practically, an ideal ruler; on the other hand, his unlimited power over people, animals and demons made him conceited and arrogant. The king was punished for his pride: his magic ring was lost and people immediately ceased to recognize him, his throne was usurped by demon (or genie - according to the

1 The chronological scope of this study is established in accordance with the existing tradition of periodization of Persian-language literature. Traditionally, the term "classical" refers to literature in the New Persian language produced between $10^{\text {th }}$ and $15^{\text {th }}$ centuries. This time is considered to be the formative period for the Persian literary canon, first of all for the poetry. Writings of this period are characterized by a certain stylistic and thematic unity [1, p. 15]. 
Qur'anic version), who took his form, and he himself was exiled. "Certainly We tried Solomon, and We cast upon his throne a mere body; then he repented"2 [38:34].

This duality of the image implies its dual use in Persian poetry: as a flattering comparison in eulogy and sometimes in lyrical poetry, and as an instructive element in religious and didactic works. It appears reasonable to base the discussion about the use of Sulaymān's image in eulogies on those typical features which literary and religious tradition has endowed this character with. Perhaps for the western reader Solomon/Sulaymān is most renowned for his wisdom. This feature characterizes Sulaymān (and, accordingly, the person to be praised) first and foremost as a good and prudent ruler. Such an example can be found in a qașīda by Anvarī (1126-1189), praising Sultan Sanjar (ruled 1118-1153):

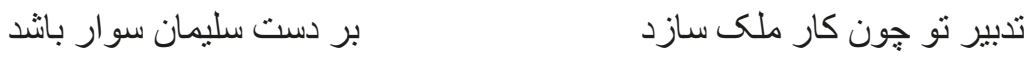

Anvarī [10, p. 89]

Your judgment, when it runs affairs of the state,

will rest on a hand [as the ring] of Sulaymān.

However, when comparing the praised one with Sulaymān poets focused usually not on wisdom and prudence, but on power and greatness of the ruler. In famous qașìda "Mother of Wine" by Rūdakī (858-941) we find probably the very first mention of Sulaymān in classical Persian literature in this context:
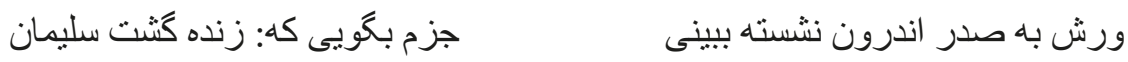

Rūdakì [11, p. 101]

If you see him sitting in a place of honour, you will only say: Sulaymān has come back to life.

Farrukhī (980-1037) also uses image of Sulaymān to praise a skillful ruler and commander:

$$
\text { در جهاندارى به ملى و در عدو بسنن به جنى هم سليمان را قرينى هم فريدون را بديل }
$$

Farrukhī [12, p. 224]

In ruling the state and capturing the enemy in a war you are like Sulaymān and will replace Farīdūn.

Examples where the name of the person being praised matches that of the Quranic prophet are of particular interest. In such cases poets usually could not resist the temptation to use wordplay to emphasize the resemblance of their patron to the legendary king not only in greatness, power and wisdom, but also in the name itself. Such lines were dedicated to Khāqān Sulaymān Khān by Rashīd ad-Dīn Vațaaț (1080/81-1177/78 or 1182/83):
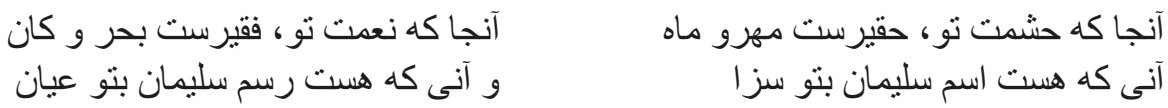

${ }^{2}$ Here and henceforth the Qur'an is cited by Arberry's translation 
Rashīd ad-Dīn Vațvāt [13]

Where your glory is, the sun and the moon are insignificant, where your mercy is, the sea and the mine are meagre.

You are the one, who befits Sulaymān's name, you are the one to whom Sulaymān's tradition is clear.

In the context of comparison, Sulaymān's image is often used next to the image of another legendary king who has become a symbol of an ideal ruler in poetry - Jamshid (Jam), It is not uncommon for these images to be contaminated. This becomes apparent when the name of Jamshīd is used in episodes clearly related to Sulaymān, e.g., the motif of possessing power ring, or related to Sulaymān's vizier, Āṣif:

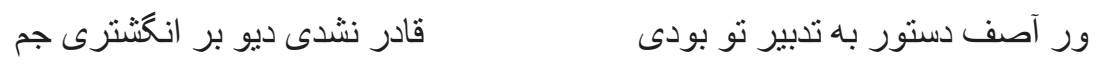

Mu'izzī [14, p. 478]

And if Āsif the counselor had been in service to you, demon would have never possessed the ring of Jam.

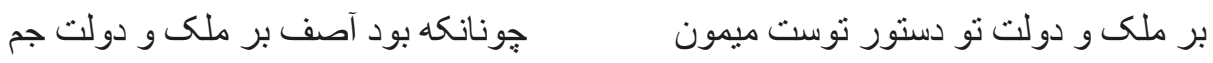

Mu'izzī [14, p.492]

Your counselor in your kingdom and wealth, is blessed just as Āṣif in the kingdom and wealth of Jam.

The fact of such contamination is widely known and has been mentioned many times by different researchers (for example [15, p. 145]). Dizfūliān and Șuhrāyī note that the reasons for this kind of contamination could have been both mistakes of scribes as well as deliberate emphasizing of the connection between these characters. Common features include power available to both kings, might, size of the territory under their rule and the fact that the time of their reign is considered to be a "golden age", as well as the fact that they both had a share of authority not only in the affairs of the state but also in relation to religious tenets $[9$, p. $77-78]$. Possibly, by using this kind of contamination the poets deliberately sought to emphasize the succession of Islamic art in relation to the old Zoroastrian traditions.

Inseparable from the motifs of Sulaymān's power is the theme of pride and humility, as well as the discussion of vanity and righteousness which has been given special importance in religious-mystical poetry. All of Sulaymān's might, majesty and wealth according to Sufi doctrine are regarded as something valuable only in the material, earthly world, something that is easy to lose and that will inevitably be lost upon entering the other world. Reference to Sulaymān's wealth and the power given to him by the ring may be used as a reminder of the frailty of earthly life:

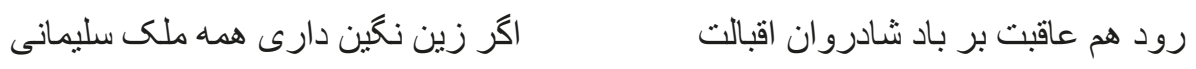

Khvājū Kirmānī [16, p. 497]

In the end, the tent of thine happiness will be carried away by the wind, [even if] through that ring thou possessest the whole kingdom of Sulaymān. 
In didactic poetry Sulaymān's wealth is usually mentioned in the context of appeal to be humble and content with minor things:

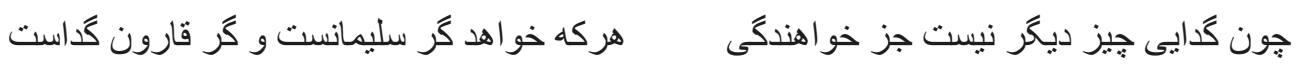

Anvarī [17]

Since begging is nothing [else] but desiring,

everyone who desires [something], regardless of whether he is Sulaymān or Qārūn, is a beggar.

\section{Structure of the image}

In the aspect of composition, image of Sulaymān is constructed from a set of motifs based on the Quranic stories. We will try to show how each story has received literary interpretation on the example of separate poetic passages.

Sulaymān and ants. The narrative of the conversation between Sulaymān and the ants is one of the most frequently used of all stories associated with this Quranic prophet. This episode is often seen as a demonstration of justice by a mighty ruler even towards the smallest creatures in his kingdom:
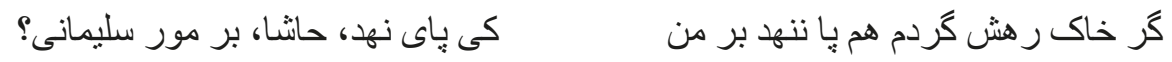

'Irāqī [18, p. 291]

If I become ashes in her way, she will not step on me -

Oh no, how can she step on Sulaymān's ant?

In the combination of motifs based on the story of Sulaymann's meeting with the ants, the main technique is an opposition. These motifs are used when the author wants to show the contrast between wealth and poverty, power and weakness, spiritual nobility and dishonesty. Such a comparison may appear in the context of preaching humility and humbleness:

$$
\text { نظر كردن به درويشان منافى بزركى نيست سليمان با جنان حشمت نظر ها بود با مورش }
$$

Ḥāfiz [19]

Looking at dervishes is not contrary to greatness,

[After all] Sulaymān, with all his splendor, looked at an ant many times.

The opposition "Sulaymān vs. ant" is also found in ghazals, where a lyrical hero tells that he is not worthy of his beloved's attention:

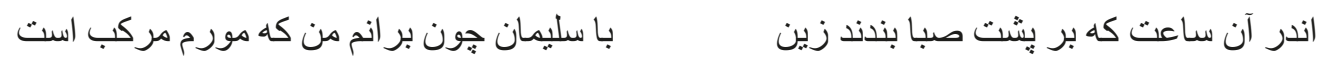

Ḥāfiz [20]

In the hour when a saddle is put on the back of the wind, how can I chase Sulaymān if an ant serves as my horse?

The story about Sulaymān and the ants is also used in philosophical poetry. In such cases, Sulaymān is compared with God and the ants are equated with his creations: 

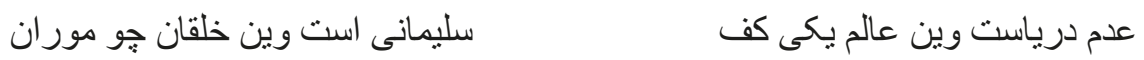

Rūmī [21, vol. 4, p. 167]

Nothingness is the sea, and this world is foam, there is [only] one Sulaymān, and these creatures are like ants.

Below are a couple of examples of using images of Sulaymān and the ants in a philosophical and mystical context. In these ghazals Rūmī compares ants with vile desires of sensual soul, which disappear when mystical love identified with Sulaymān appears:

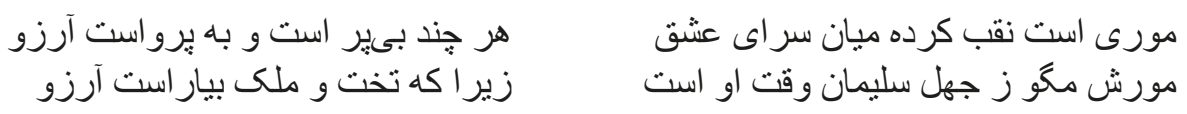

Rūmī [21, vol. 5, p. 77]

He is an ant who undermined the Palace of Love.

Although he has no wings but he dreams of passion.

Do not call him an ant in ignorance, he is the Sulaymān of his time,

for he had a dream of throne and kingdom.

$$
\text { رفتند به سور اخ خود از بيم تو موران }
$$

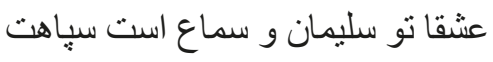

Rūmī [21, vol. 4, p. 163]

Oh, love, you are Sulaymān, and șamā'3 is your army!

In fear of you, ants have hidden in their holes.

In such comparisons, as we can see, authors sometimes go quite far from the original Qur'anic narrative of Sulaymān and the ants where this episode is described very briefly and the main emphasis is placed on justice and modesty of Sulaymān who with all his greatness and power condescended not to trample the houses of ants on the way of his army.

Another story which must be mentioned when talking about Sulaymān and the ants is about an ant that once came to the court of King Sulaymān with a very modest gift a locust leg. The original source of this legend is unclear, but it has become so firmly entrenched in Persian-language poetic tradition that it formed a stable metaphor: a locust leg (or a gift of an ant) is a very small favor or a useless gift which nevertheless took a lot of effort to prepare. There’s a proverb: باى ملخ يِش سليمان بردن/فرستادن - literally “To send a

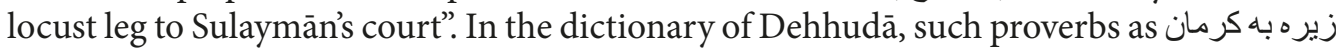
بردن (“To bring cumin to Kerman”) and خرما سوى هجر بردن (“To bring dates to Hadjer”) [22, vol. 4, p. 4714] are given as synonyms to this expression.

In poetry the story of an ant giving Sulaymān a locust leg can be used in the context of the author's self-abasement, when he presents his modest literary work to his patron:
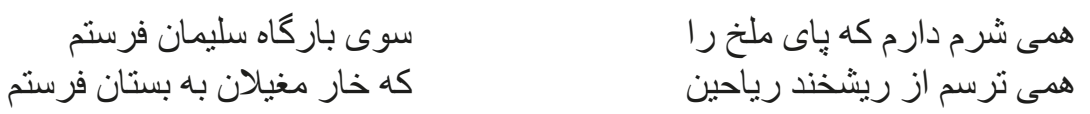

${ }^{3}$ Samä (صماع) - is a special kind of sufi gathering where music was performed, poetry and Qur'anic verses were read for the purpose of meditation. 
Anvarī [23]

I'm ashamed to send a locust leg to Sulaymān's court,

I'm afraid of the mockery of basil, because I'm sending a thorn to the flower garden.
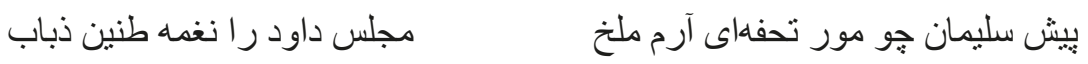

'Irāqī [18, p. 69]

Like an ant, I am bringing a locust as a present to Sulaymān -

[This is like] a song of insect buzzing for Dāvud's gathering.

However, despite the fact that for the mighty king a locust leg is a rather modest offering, for the ant it was worth a lot of work, and Sulaymān did not ignore his efforts and appreciated this gift and singled it out among all other gifts that were brought to his court. From this point of view, the narrative of an ant and locust leg can be seen in the context of moral teachings: whatever gift is made to you, be grateful, for it is not a gift that is valuable, but the effort.
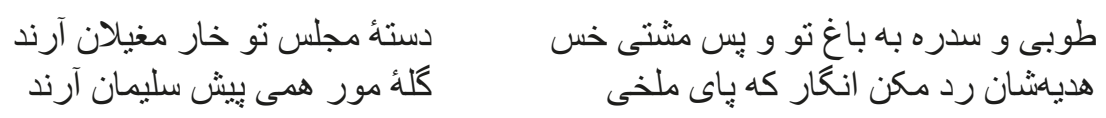

Sanāì [24, p. 142]

In thy garden there are Țūbā tree of Paradise and the Lote-Tree of the Utmost Boundary ${ }^{4}$

And then a handful of unworthy people brings a bunch of thorny shrubs to your meeting.

Don't reject their gift -

it's like a swarm of ants brings a locust leg to Sulaymān.

The ring of Sulaymān. Sulaymān's ring is an essential attribute of this king and the source of his power over animals, demons and winds.

$$
\text { شاد باش اى شرع بى تو همجو موسا بىعصا دير زى اى علم بى تو جون سليمان بىنكين }
$$

Sanāì [24, p. 724]

Oh, be happy! Sharia“ without you is like Mūsā without his staff.

Oh, live long! Science without you is like Sulaymān without his ring.

By saying "power" we are referring not only to royal power, but also to the kind of power that beloved one has over the heart of lover:

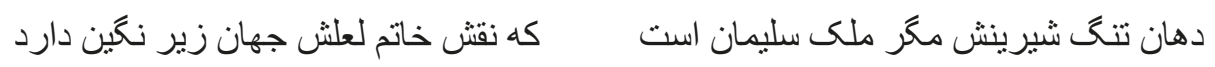

Ḥāfiz [26]

Her slender sweet lips are like the kingdom of Sulaymān,

For the carving of her ruby signet-ring (i.e. her lips) has subdued the world.

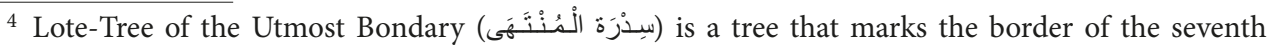
heaven which no living creature can pass. The only one allowed beyond this boundary was Muhammad on the night of the Míräj [25, p.92]. 
In the example above Hāfiz plays with the image of Sulaymān's ring and expression ن - نشاد نى - "to rule, to govern", and literally "to have [somebody] under the ring".

However, in most cases, the image of Sulaymān's ring appears in the context of motifs related to the Quranic story about the exile of Sulaymann and the seizure of power by the demon. Mu'izzī uses this motif to praise masterful leadership:

$$
\text { ديوكى بردى ز دستش خاتم وناج و سرير }
$$$$
\text { ور سليمان جون تو دستور مميز داشتى }
$$

Mu'izzī [14, p. 362]

And if Sulaymān had an excellent counselor like you,

How could a demon steal from him his ring, crown and throne?

The motif of the lost ring and loss of power is used particularly often in didactic and mystical Sufi poetry. The topics of pride and humility, vanity and righteousness, as well as the frailty of human life run through all the motifs associated with the image of prophet Sulaymān. Ousting Sulaymān from his throne, which was a punishment for the king's excessive pride and conceit, is one of the central episodes of Sulayman's entire narrative. From this point of view, the comparison of a patron to this prophet takes rather form of warning and moral:

$$
\begin{aligned}
& \text { از كفت خو اهد ربود انكشترين غافل مباش } \\
& \text { سحر ديو انست در زير نكين غافل مباش الش }
\end{aligned}
$$

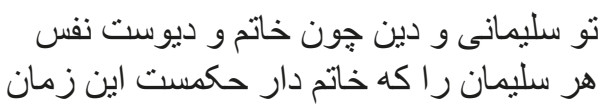

Sayf Farghānī [27, p. 240]

You are Sulaymān, the faith is like a ring, and demon is a sensual soul.

From your hand [he] will steal this ring - do not be reckless.

To every Sulaymān who possesses the ring of command at this time

The witchcraft of demons has been submitted - do not be reckless.

The image of Sulaymān is also often associated with piety. In the following example, we see how Jalāl ad-Dīn Rūmī uses the image of a ring as an allegory of righteousness:

$$
\text { به روزه باش كه آن خاتم سليمان است مده به ديو تو خاتم مزن تو ملك به هم }
$$

Rūmì [21, vol. 4, p. 68]

Keep your fast, for this is Sulaymān's ring.

Don't give demon the ring, don't destroy your state.

Sulaymān and demons. Motifs of Sulaymān's power over the demons give poets numerous opportunities to compare their patrons with this Qur'anic character. One of the favorite images of Persian poets is demons working for Sulaymān. The praised ruler is usually compared to Sulaymān, and his enemies to demons:

$$
\text { زدمات بر مدت عمر نو مقصور }
$$

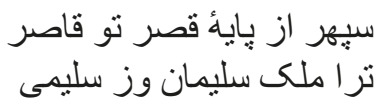

Anvarī [10, p. 157]

The sky is lower than the foot of your castle, [All the] time is limited compared to the time of your life. 
The kingdom of Sulaymān is yours, and in obedience your enemy is the demon laborer in [your] abode.

The image of the demon (div in Persian) often appears in Sufi poetry: like the ant, it is opposed to Sulaymann as the low to the sublime, the earthly to the divine, and the sensual soul to the divine spirit:

$$
\text { جون برود صبر و خرد نفس تو اماره شود }
$$$$
\text { جونك سليمان برود ديو شهنشاه شود }
$$

Rūmì [21, vol. 2, p. 13]

When Sulaymān leaves, demon becomes the shah.

When patience and reason are gone, your sensual soul takes over.

Sulaymän's power over the wind. Sulaymān's power over the wind is mentioned three times in the Qurān: 38:36, 21:81 and 34:12. It is noteworthy that the general trend is towards the use of a semantic connotation of lightness and tenderness: poets usually used the neutral word باد (mind) or (morning refreshing wind) to indicate the wind. The latter word can often be seen next to the consonant name of the country whose ruler was Bilqīs - Sabā (سبا).

$$
\text { خاصسه جون هدهد به دركاه سليمان مى رسد }
$$$$
\text { اي صبا فرّ اشى فرش سبا كن دم به دم }
$$

Ibn Ḥisām Khūsfī [28]

Oh, morning breeze, be a servant at the spread carpet of Sabā every moment, Especially when hoopoe reaches Sulaymān's court.

There are two main duties that Sulaymān's wind performed: first, he served the king as a vehicle, and second, he could deliver him rumours and news from all over the world [9, p. 29-30]. In the role of transport, the wind is often mentioned together with the throne Bilqīs or the Sulaymān himself, flying or floating in the air:

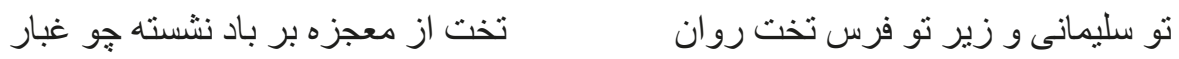

Anvarī [10, p. 141]

You are Sulaymān, and under you is a horse [like] a moving throne.

The throne magically rests on the air like a fog.
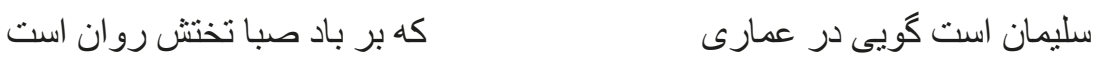

Sa'di $[29$, p. 568]

You would say that he is Sulaymān, [sitting] in his palanquin, For his throne rests on the morning breeze.

The wind as Sulaymān's messenger is often referred to in the context of the meeting of Sulaymān's army with ants: according to some versions, it was the wind that brought the weak voice of an ant to the king's ears.

$$
\text { قصده مور ار به سليمان رسى }
$$$$
\text { لطف كن ای باد صبا عرضه دار }
$$ 
'Imād Faqīh [8, p. 30]

Do me a favor, oh, morning breeze, tell

The story of an ant if you reach Sulaymān.

كه باد و اقعه مور با سليمان كفت

صبا به داور دور ان رسان حكايت من

Ibn Hisām Khūsfī [30]

Wind, bring my story to the judge of the ages,

As the wind told about what happened to ants to Sulaymān.

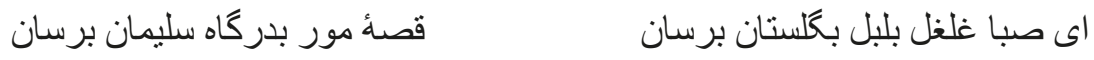

Khvājū Kirmānī [16, p.483]

Oh, wind, bring the singing of the nightingale to the flower garden,

Bring the story of an ant to the court of Sulaymān.

As in the case of motifs associated with Sulaymān's ring, while referring to the wind, poets often resorted to the wordplay based on common Persian phraseological expressions, such as به/بر باد رفتن (to die, to be destroyed, to be wasted, literally "to be scattered in the wind").

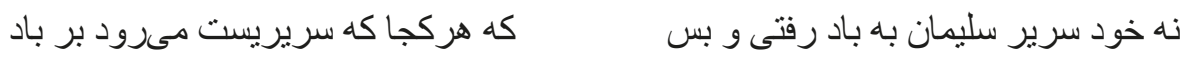

Sa'dī [29, p. 950]

Wasn't Sulaymān's throne carried away by the wind - and that's it?

For wherever there is a throne, it will go with the wind.

$$
\text { در معرضى كه تخت سليمان رود به باد }
$$

بادت به دست باشد اكر دل نهى به هيتج

Hāfiz [31]

There shall be [only] a wind in thy hands, if thou shalt put thy whole heart into naught

[as] in the case of the throne of Sulaymān, [which] was carried away by the wind.

Another phraseological expression which often appears in the context of moral teachings about the futility of earthly existence and which emphasizes Sulaymān's connection with the wind is كره بر/به باد زدن that is to rely on the corrupted world, on human life (literally "to tie a knot on the wind"):

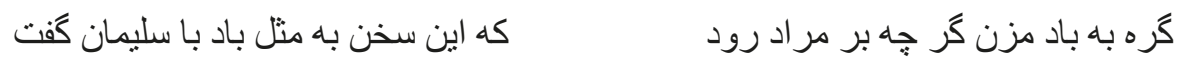

Hāfiz [32]

Do not rely on the wind, even if it blows towards your desires,

For it is like words that the wind said to Sulaymān.

Language of the birds. The motifs of Sulaymān's power over birds and his ability to understand their language are particularly important in revealing the character's image and understanding his role in Persian classical literature. A special place among these motifs is occupied by the image of hoopoe. Due to the Qur'anic story about the flight of 
hoopoe to the state of Sabā medieval poets viewed this bird primarily as a messenger of Sulaymān:

$$
\text { نامه يى سوى سبا بردم دكر باز آمدم }
$$

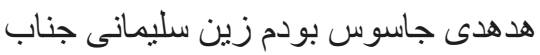

Sayf Farghānī [33, vol. 2, p. 313]

I was a hoopoe-spy for this Sulaymān-wise governor,

I took the letter to Sabā and went back.

The hoopoe is often mentioned together with another messenger of Sulaymān — the wind, or even compared with it:
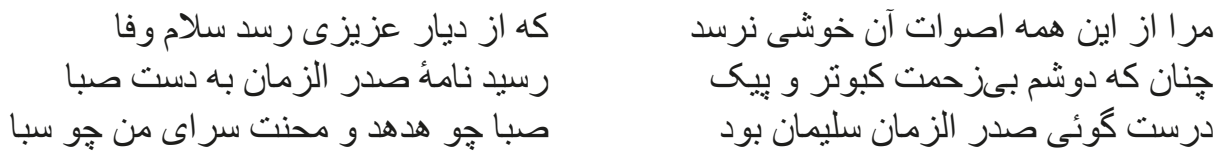

All these sounds do not bring me that sweetness

which is brought by the avowal of fidelity [coming] from the land of my friend.

Like yesterday, without the labors of a pigeon or a messenger,

a letter from the Lord of time has been brought to me by the wind

You say correctly: the Lord of time is Sulaymān,

the wind is like the hoopoe, and my abode of labor is like Sabā.

One more example: the beginning of a qașīda by Salmān Sāvajī:

قاصدى نزد نبى بيغام سلمان مىبرد

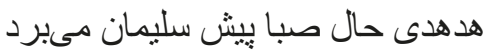

Salmān Sāvajī [34]

Hoopoe will bring [news about] the state of the wind to Sulaymān,

The messenger will bring Salmān's message to the Prophet ${ }^{5}$.

In a broader context, the image of hoopoe can be seen as a symbol of any good message (مزّد): if there is good news, people say the hoopoe brought it.

كه مزده طرب از كلثن سبا آورد

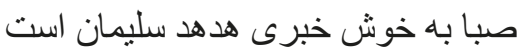

Ḥāfiz [36]

The wind in delivering good news is [like] the hoopoe of Sulaymān,

Who brought the joyful message of pleasure from the Sabā garden.

The image of the hoopoe is particularly important in mystical poetry. It will suffice to mention that in the famous poem by Farīd ad-Dīn "Ațțār "Manțiq-aț-Ṭayr" ("The conference of the birds") one of the main characters is hoopoe who acts as a mentor to other birds, guiding them on their path to self-awareness and merging with the divine Absolute represented by mythical bird Simurg. Thus, 'Atțār identifies hoopoe with murshid, the mentor, while the other birds are his disciples (muried) to whom he passes on his mystical knowledge. The role of hoopoe as Sulaymān's messenger is reinterpreted in a Sufi way: his

${ }^{5}$ Here again we see a wordplay: the name Salmān may refer to the poet himself as well as to one of the most famous associates of the Prophet Muhammad, Salmān Fārisī, the first Persian to adopt Islam [35]. 
flight to the kingdom of Sabā is the mystical connection between mind and spirit - the rationalistic and the divine - which every Sufi seeks to attain.

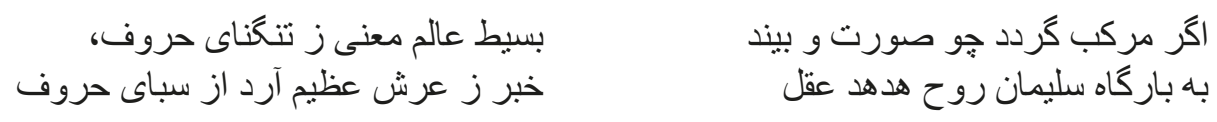

Sayf Farghānī [27, p. 22]

If ink takes shape and sees

the space of the Spiritual World through the tightness of letters,

to the court of Sulaymān-spirit hoopoe-mind

will bring news of the great throne from Sabā of words.

Sulaymān's ability to understand the language of birds is also given special meaning in mystical lyrics. The language of birds represents a special symbolic Sufi language, and Sulaymān, who speaks it, is a sheikh who can be an interpreter for those who have not yet learnt the secret knowledge:
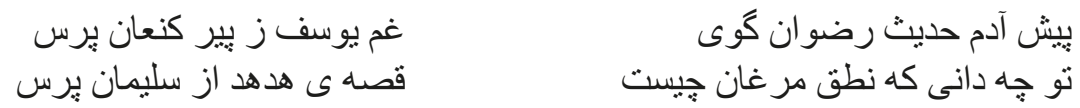

Ibn Hisām Khūsfī [37]

Tell Adam about paradise, Ask the elder from Canaan about the sorrow over Yusuf ${ }^{6}$.

What do you know of the bird language?

Ask Sulaymān about the story of the hoopoe.
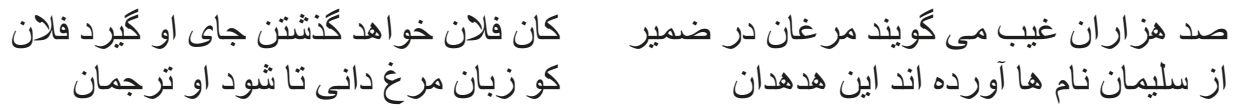

Rūmī [21, vol. 4, p. 192]

Birds in secret tell a hundred thousand mysteries

that this one is going to leave [this world] and that one takes his place.

The hoopoes brought letters from Sulaymān.

Where is he who knows the language of birds to become an interpreter?

Sometimes a poet himself acts as a hoopoe who translates the words of divine knowledge into a language people could understand and shows them the way to unite with the Absolute. In such cases, the poet draws parallels between the relationship of the hoopoe and Sulaymān and the connection between a Sufi in love and his mystical beloved. The hoopoe is considered to be a lover who needs the intimacy and help of Sulaymān, the beloved.

$$
\text { اى تو با بنده جو يوسف بازليخا در مقال بنده باتو همجو هدهد باسليمان در سخن }
$$

${ }^{6}$ An elder from Canaan - Yakub, father of Yusuf, who, according to the Qur'anic legend, cried so bitterly about his missing son that went blind [25, p. 90-100]. 
Sayf Farghānī [33, vol. 2, p. 149]

Oh, you, who is talking to [thy] slave like Yusuf to Zulaikha,

[thy] slave speaks to you like hoopoe to Sulaymān.

This is how Rümì in the conclusion of one of his ghazals addresses his friend and teacher Shams Tabrīzī:

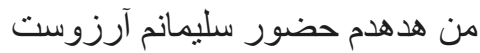

بنماى شمس مفخر تبريز رو ز شرق

Rūmī [21, vol. 1, p. 256]

Show your face in the east, glorious sun of Tabriz!

I'm hoopoe, my dream is of Sulaymān's presence.

Sulaymān and Bilqīs. The themes of mystical love are also reflected in the motifs based on the Sulaymān's meeting with the Queen of Sabā'. It is noteworthy that despite the absence of any hints of Sulaymān's and Bilqis's love affair in the Bible, at an early stage of romanization, in aggadic literature, and later in the Qur'an and in tafsirs, the story of their encounter acquires the features of a romantic love story, which could not but be reflected in poetry [38, p. 147]. This narrative is integrated harmoniously into the context of Sufi poetry and stands alongside with other traditional love stories of Persian literature:
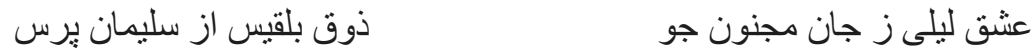

Shāh Ni'matullāh Walī [39]

Look for the love of Laylā in Majnūn's heart,

Ask Sulaymān about affection to Bilqīs.

Sulaymān and Āșif. Speaking of the image of Sulaymān, it is impossible to ignore the image of his closest counsellor - Āșif. The legendary vizier of Sulaymān is mentioned relatively rarely in the works of Persian poets - less frequently than Bilqis and much less frequently than Sulaymān himself. However, the image of Āșif is undoubtedly important for Persian poetry - it embodies the qualities needed for the shah's wise advisor and symbolizes rationality and skill in governing the state. These attributes provide a basis for comparison in panegyrics:

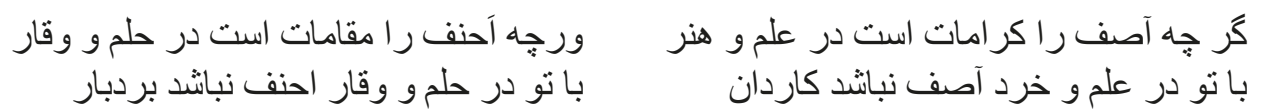

Mu'izzī [14, p. 302]

Although Āṣif has a talent in science and art and although Ahnaf ${ }^{8}$ has a [high] rank in gentleness and dignity,

Āsif is not as learned in science and wisdom as you, Ahnaf is not as strong in gentleness and dignity as you.

${ }^{7}$ In the Qur'an, Queen of Sabā is not called by name. Name "Bilqīs" apparently came to Persian literary tradition from Islamic legends, where the story of Queen of Sheba and Sulaymān was greatly enriched with details as compared with that of the Qur'an [40]. 1257].

${ }^{8}$ May be referring to Ahnaf Ibn Qays, commander and associate of Muhammad [22, vol. 1, p. 1255- 
Poets in their eulogies were required to follow a certain hierarchy when comparing theis patron with some legendary character. According to this order, the vizier was usually compared with Āșif, while the shah was compared with Sulaymān.

The poetry has adopted the version that it was Āsif who transferred the throne of Bilqīs from Sabā to the court of Sulaymān in the blink of an eye, although the Qur'an does not name the person who did it. It simply refers to a man who "possessed knowledge from the book" [27:40]:
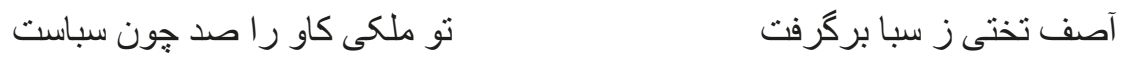

Farrukhī [12, p. 21]

Āṣif took the throne from Sabā,

[And] you [took] a kingdom that is like a thousand kingdoms of Sabā.

\section{Conclusion}

The image of Sulaymān in Persian classical poetry is versatile and could be used in various contexts. Like the images of many other Qur'anic characters, it has become deeply embedded in the system of artistic expression of medieval Persian poetic language.

The key characteristic that this image acquired during its functioning in the Persian literary tradition is its duality. Sulaymān's legendary wealth and power made it convenient to use his image as a flattering comparison in eulogies. Such metaphors could have been based on a number of Qur'anic stories and motifs. For instance, motifs of Sulaymān's power over animals and demons were particularly appropriate in cases where the name of the praised one was the same as the name of the legendary king. At the same time, didactic and mystical literature has adopted another aspect of this image. The narrative about Sulaymān's dethronement became an instructive story of arrogance and punishment.

Sulaymān's image has an inherent connection with a range of other Qur'anic images. Thus, Sulaymān's ring as well as his throne are used as indication of power and wealth. Sufi poetry uses images of the throne that was taken by the wind and the ring stolen by demon as an illustration of frailty and transience of earthly goods. The image of a tiny ant is often contrasted with the power of the king while ant's present - locust leg - became a symbol of an offering that is valuable not in itself but as a demonstration of effort. A major role in the complex of motifs associated with Sulaymān is played by the images of his magical helpers: demons, winds, birds, as well as his wise advisor - Asif. The ability to understand the language of birds attributed to Sulaymān allowed poets to bring him into a comparison with a sheikh who translated the words of mystical knowledge for his disciples into a language they could comprehend. At the same time, the hoopoe could be identified both with a mentor (in relation to other birds) and with a disciple and lover (in relation to Sulaymān). The image of Bilqis is involved mostly in metaphors describing mystical love.

\section{Acknowledgement}

The present article is based on the author's master's thesis that was written under the supervision of O.M. Yastrebova to whom I express my deepest gratitude. I also take this opportunity to express my gratitude to the supervisor of my $\mathrm{PhD}$ work $\mathrm{Y}$. A. Ioannesyan. 


\section{References}

1. Rejsner M.L., Ardashnikova A. N. Persian literature of $9^{\text {th }}-17^{\text {th }}$ centuries. 1 vol. Persian literature of the Pre-Mongol time, ed. by E. O. Akimushkina. Moscow, Sadra Publ., 2019. 392 p. (In Russian)

2. Bertel's A.E. Artistic Image in the Art of Iran of $9^{\text {th }}-15^{\text {th }}$ centuries (Word, picture). Moscow, Vostochnaia literatura Publ., 1997. 422 p. (In Russian)

3. Rejsner M. L. Quranic story of Yusuf in Persian classics of $10^{\text {th }}-15^{\text {th }}$ centuries (lyrical motif and novel narrative). Vestnik Moskovskogo universiteta. Serija 13. Vostokovedenie, 2014, no. 4, pp. 4-16. (In Russian)

4. Rejsner M.L. Miracles as an element of fictionalization of Yusuf's (Joseph's) story. Iranistika $v$ Evrazii: proshloe, nastojashhee, budushhee: Sbornik statej, ed. by P. V. Basharin. Moscow, RGGU Publ., 2018, pp. 100-109. (In Russian)

5. Prigarina N.I. Yusuf's beauty in the mirrors of Persian poetry and miniature painting. Prigarina N. I. Mir pojeta - mir pojezii. Stat'i i jesse. Moscow, Institut vostokovedeniia RAN Publ., 2012, pp. 191229. (In Russian)

6. Schimmel A. Yusuf in Mawlana Rumi's poetry. The Heritage of Sufism. Vol. 2. The legacy of Medieval Persian Sufism (1150-1500), ed. by L. Lewisohn. Oxford, Oneworld Publications, 1999, pp. 45-61.

7. Schimmel A. Jesus and Mary as poetical images in Rūmìss verse. Christian-Muslim encounters, ed. by Y. Yazbeck Haddad and W.Zaidan Haddad. University Press of Florida, 1995, pp. 143-157.

8. Dāvarī P. Influence of the Quranic story of Sulaymān on Persian literature. Fasslnāma-yi naqd va adabīyāt-i tạtbiqī (pazhūheshhā-i zabān va adabīyāt-i 'arabī). Dānishkada-yi adabìyāt va 'ulūm-i insānì (Dānishgāh-i rāzīi-yi Kermānshāh), 2012, no. 5, pp. 23-52. (In Persian)

9. Dizfūliān K., Șuhrāyī Q. Contamination of stories of Sulaymān and Jamshīd and its reflection in Persian literature. Majalla-yi muțāli'ātti ìrānn̄ (Dānishkada-yi adabiyāt va 'ulūm-i insānā), 2011, no. 11, pp. 75-91. (In Persian)

10. Anvarī. Dīvān, ed. Sa`ìd Nafīsī. Intishārāt-i Sikka, 1364 (1985). 629 p. (In Persian)

11. Rūdakī Samarqandī. Dìvān, ed. Sa'īd Nafīsī, I. Brāgīnskij. Mu’assisa-yi intishārāt-i nigāh, 1376 (1997). 216 p. (In Persian)

12. Farrukhī Sīstānī. Dìvān, ed. 'Alī 'Abd ar-Rasūlī. Matbaee-yi majlis, 1311 (1932). 447 p. (In Persian)

13. Vạtvāt, Rashīd ad-Dīn. Qasīda. Ganjoor.net: Āthār-i sokhansarāyān-i pārsìgū. Available at: https:// ganjoor.net/vatvat/ghasv/sh155/ (accessed: 09.03.2020). (In Persian)

14. Mu'izzī. Dìvān, ed. 'Abbas Iqbāl. Kitābfurūshī-yi islāmiya, 1318 (1939). 868 p. (In Persian)

15. Rejsner M.L. Persian lyrico-epic poetry of $10^{\text {th }}$-beginning of $13^{\text {th }}$ century: genesis and evolution of classic qasida. Moscow, Natalis Publ., 2006. 423 p.

16. Khª̄jū Kirmānī. Dìvān, ed. Aḥmad Suhaylī Hª̄nsārī. Tiḥrān, Intishārāt-i Pāzhnag, 1369 (1990). 830 p. (In Persian)

17. Anvarī. Qit’a. Ganjoor.net: Āthār-i sokhansarāyān-i pārsīgū. Available at: https://ganjoor.net/anvari/divan-anvari/ghetea/sh40/ (accessed: 09.03.2020). (In Persian)

18. 'Irāqī, Fahr ad-Dīn. Collected poetry, ed. Sa'īd Nafīsî. Tiḥrān, Sanāī. 443 p. (In Persian)

19. Hāifiz. Ghazal. Ganjoor.net: Āthār-i sokhansarāyān-i pārsìgū. Available at: https://ganjoor.net/ hafez/ghazal/sh278/ (accessed: 09.03.2020). (In Persian)

20. Hāfiz. Ghazal. Ganjoor.net: Āthār-i sokhansarāyān-i pārsīgū. Available at: https://ganjoor.net/ hafez/ghazal/sh31/ (accessed: 09.03.2020). (In Persian)

21. Maulavī, Jalāl ad-Dīn Muhammad bin Muhammad. Collected poetry of Shams or Big Dīvān. 10 vol, ed. Badī‘ az-Zamān Firūzānfar. Tiḥrān, Amīr-i kabīr, 1378 (1999). (In Persian)

22. Explanatory dictionary. 14 vol. Ta’līf-i 'Alī Akbar Dehhudā, mu’assisa-yi intishārāt va chap-i Dānishgāh-i Tiḥrān, 1993-1994. (In Persian)

23. Anvarī. Qit’a. Ganjoor.net: Āthār-i sokhansarāyān-i pārsīgū. Available at: https://ganjoor.net/anvari/divan-anvari/ghetea/sh334/ (accessed: 09.03.2020). (In Persian)

24. Sanāì Ghaznavī, 'Abū-l-Madzhdūd bin Ādam. Dìvān, ed. Mudarris Raḍavī. Tị̣rān, Sanāì, 1362 (1983). 1227 p. (In Persian)

25. Drozdov V. A. Towards the problem of the Sufi terminology. Neizmennost' i novizna hudozhestvennogo mira. Pamjati E. Je. Bertel'sa. Sbornik statej, ed. by N. V. Kolesnikova. Moscow, Institut vostokovedenija RAN Publ., 1999, pp. 86-107. (In Russian)

26. Hāāiz. Ghazal. Ganjoor.net: Āthār-i sokhansarāyān-i pārsīgū. Available at: https://ganjoor.net/ hafez/ghazal/sh121/ (accessed: 09.03.2020). (In Persian)

27. Sayf Farghānī. Dīvān. Complete edition, ed. Zabīḥullah Șafā. Tiḥrān, 1364 (1985). (In Persian)

28. Ibn Ḥisām Hūūfī. Ghazal. Ganjoor.net: Āthār-i sokhansarāyān-i pārsīgū. Available at: https://ganjoor.net/ebnehesam/ghazalebn/sh80/ (accessed: 09.03.2020). (In Persian) 
29. Sa'adī Muṣliḥ ad-Dīn. Collected poetry, ed. Muḥammad'alī Farūgī. Tị̣rān, Hirmis, 1385 (1996). 1406 p. (In Persian)

30. Ibn Ḥisām Ḥūsfī. Ghazal. Ganjoor.net: Āthār-i sokhansarāyān-i pārsīgū. Available at: https://ganjoor.net/ebnehesam/ghazalebn/sh28/ (accessed: 09.03.2020). (In Persian)

31. Hāfiz. Ghazal. Ganjoor.net: Āthār-i sokhansarāyān-i pārsīgū. Available at: https://ganjoor.net/ hafez/ghazal/sh100/ (accessed: 09.03.2020). (In Persian)

32. Hāfiz. Ghazal. Ganjoor.net: Āthār-i sokhansarāyān-i pārsīgū. Available at: https://ganjoor.net/ hafez/ghazal/sh88/ (accessed: 09.03.2020). (In Persian)

33. Sayf Farghānī. Dìvān. 3 vol., ed. Zabīhullah Șafā. Tiḥrān, Intishārāt-i dānishgāh-i Tị̣rān, 1344 (1965). 872 p. (In Persian)

34. Salmān Sāvajī. Qasīda. Ganjoor.net: Āthār-i sokhansarāyān-i pārsīgū. Available at: https://ganjoor. net/salman/divanss/ghasidess/sh32/ (accessed: 09.03.2020). (In Persian)

35. Vida G. Levi Della. Salmān al-Fārisī. Encyclopeedia of Islam, ed. by P. J.Bearman, Th. Bianquis, C. E. Bosworth, E. van Donzel and W. P. Heinrichs et al. $2^{\text {nd }}$ ed., vol. 12. Leiden, Brill, 2004, pp. 701-702.

36. Ḥāfiz. Ghazal. Ganjoor.net: Āthārr-i sokhansarāyān-i pārsīgū. Available at: https://ganjoor.net/ hafez/ghazal/sh145/ (accessed: 09.03.2020). (In Persian)

37. Ibn Hisām Hūsfī. Ghazal. Ganjoor.net: Āthār-i sokhansarāyān-i pārsīgū. Available at: https://ganjoor.net/ebnehesam/ghazalebn/sh94/. (In Persian)

38. Piotrovskii M. B. Qur'anic stories. Moscow, Nauka, Glavnaia redakciia vostochnoi literatury Publ., 1991. 219 p. (In Russian)

39. Shah Ni'matullah Walī. Ghazal. Ganjoor.net: Āthär-i sokhansarāyān-i pārsīgū. Available at: https:// ganjoor.net/shahnematollah/ghazalshv/sh918/ (accessed: 09.03.2020). (In Persian)

40. Ullendorff E. Bilkīs. Encyclopæedia of Islam, ed. by P. J. Bearman, Th. Bianquis, C. E. Bosworth, E. van Donzel and W. P. Heinrichs et al. $2^{\text {nd }}$ ed., vol. 1. Leiden, Brill, 1986, pp. 1219-1220.

Received: April 22, 2020 Accepted: June 29, 2020

Author's information:

Anna V.Moiseeva - moiseeva3927@gmail.com

\title{
Пророк Сулайма̄н в классической персидской поэзии: семантика и структура образа
}

\author{
A. B. Моисеева \\ Институт восточных рукописей РАН, \\ Российская Федерация, 191186, Санкт-Петербург, Дворцовая наб., 18
}

Для цитирования: Moiseeva A. V. Prophet Sulaymān in Classical Persian Poetry: Semantics and Structure of the Image // Вестник Санкт-Петербургского университета. Востоковедение и африканистика. 2020. T. 12. Вып. 3. С. 398-414. https://doi.org/10.21638/spbu13.2020.306

Статья посвящена рассмотрению структуры, смыслового содержания и особенностей функционирования образа коранического пророка Сулайма̄на (библейского Соломона) в персидской средневековой поэзии. На основе анализа поэтического материала делается вывод об основных сферах применения этого образа и его семантических коннотациях как в панегирической, так и в религиозно-мистической поэзии. Определяются основные мотивы коранической истории этого пророка, вошедшие в персоязычную поэтическую традицию, и то, как они соотносятся с различными темами, которые поэты затрагивают в своих стихах. Так, в панегириках, сравнивая своего патрона с Сулайма̄ном, поэты обращались к мотивам власти этого царя над ветрами и демонами, а также к связанным с ними образам трона и кольца, дарующего могущество. В суфийской поэзии особое место заняли образ удода и мотив языка птиц, которые 
раскрывают темы отношений ученика и наставника и руководства на пути мистического познания. В качестве глобальной характеристики образа Сулайма̄на можно упомянуть его неоднозначность, берущую корни еще в библейском повествовании, где наряду с мудростью упоминается излишняя горделивость этого царя. В позднейших комментариях появилась история о свержении с трона и захвате власти дивом в качестве наказания, ниспосланного Сулайма̄ну. Эти темы нашли свое отражение в коранической традиции, а оттуда перешли и в персидскую литературу в виде мотивов смирения и бренности земной жизни, которые получили особое значение в дидактической и мистической поэзии.

Ключевые слова: персидская поэзия, образ, пророк Сулайма̄н, истории пророков в Коране, сюжет, мотив.

Статья поступила в редакцию 22 апреля 2020 г., рекомендована к печати 29 июня 2020 г.

Контактная информация:

Моисеева Анна Владимировна - moiseeva3927@gmail.com 